\title{
Commentary
}

\section{Sustainability Planning as Paradigm Change}

\author{
Stephen M. Wheeler \\ Department of Human Ecology, University of California Davis, Davis, CA 95616, USA; E-Mail: smwheeler@ucdavis.edu
}

Submitted: 31 August 2016 | Accepted: 14 September 2016 | Published: 9 November 2016

\begin{abstract}
The theme of the next issue of Urban Planning will be Paradigm Shifts. To make the link between "sustainability" and "paradigm change," the following commentary analyzes the former concept as a main example of the latter. Although it is often applied to rather modest planning initiatives, "sustainability" can be seen as requiring shifts in cognitive paradigm that are transformational, radical, and not yet fully appreciated by most of those who use the term. Specifically, this term implies a proactive, results-oriented approach (e.g. initiatives to actually meet GHG reduction targets), a long-term viewpoint (e.g. planning for 50 or $100+$ years in the future), and a holistic or ecological mindset able to understand dynamic, evolving systems. This last change is the most difficult and requires thinking across scales of action, across time frames, across issue areas and goals (e.g. the "Three E's" of environment, economy, and social equity), and across communities. It also means integrating different types of actions into a broader program of social change. Though challenging, these cognitive shifts can lead to radically different outcomes than past urban planning.
\end{abstract}

\section{Keywords}

paradigm change; sustainability; sustainable development; urban planning

\section{Issue}

This commentary is part of the issue "Sustainable Planning and Technologies", edited by Hatem Ibrahim (Qatar University, Qatar), Ahmed Khan (Université Libre de Bruxelles, Belgium), Steffen Lehmann (University of Portsmouth, UK), Dellé Odeleye (Anglia Ruskin University, UK) and Atiq Zaman (Curtin University, Australia).

(C) 2016 by the author; licensee Cogitatio (Lisbon, Portugal). This article is licensed under a Creative Commons Attribution 4.0 International License (CC BY).

The topic of "paradigm shifts" is a great one for this journal, and challenges us to come up with new ways of thinking so that planners can address many problems of the twenty-first century. As one contribution to this conversation I would like to reflect on the concept of "sustainability planning." In the current era almost every institution has some actions it can point to as proof of its sustainability commitment. Is "sustainability" just a meaningless buzzword or planning fad that has already played itself out? Or does it connote a fundamental paradigm shift with relevance far into the future? In this short commentary I will argue that "sustainability" refers to shifts in worldview that are transformational, radical, and not yet fully appreciated by most of those who use the term.

Let me start with an example of how the term can be used uncritically. While preparing for a trip recently I read an English-language summary of the city of Oslo's sustainability planning, which to be sure includes many impressive achievements and accolades including a Euro- pean Sustainable City Award in 2003. However, the website argued that:

"Oslo has already successfully been a sustainable city for 1,000 years and with the plans and actions put forward in the realization of goals [it can be] more sustainable for the next 1,000 years." (Sustainable Oslo, 2016)

Fractured English aside, this rather self-congratulatory statement epitomizes some common interpretations of "sustainability" that detract from its potential paradigm shift role. First of all, the author equates "sustaining" with "surviving," when I think most of us would wish for something considerably more than mere survival. In its thousand-year history Oslo was destroyed multiple times by fire and decimated by the plague; arguably it is lucky to have survived at all. Its restrictive nineteenth-century society helped inspire artist Edvard 
Munch's world-famous painting "The Scream," not something that most cities would want to brag about. Just having survived to date is no guarantee that communities are healthy and livable places, or that they will thrive in the future. Seeing sustainability as mere survival is a cop-out.

The statement's focus is also just on Oslo and not on its relation to the rest of the world. However, given Norway's role as a leading oil producer and arms exporter, never mind the ecological footprints of some 1.7 million Oslo-area residents, its impacts on other places are certainly sizable. These links must be taken into account. Sustainability should not just be about preserving one relatively well-off place in isolation.

Lastly, this website seems to assume that developing plans, actions, and goals primarily on environmental topics is enough to address sustainability problems. Instead, social dynamics and values must be considered as well. Oslo was in fact forced to reevaluate its own social health after July 22, 2011, when a right-wing Norwegian set off a car bomb downtown and then opened fire at a camp outside the city, killing 77 people in all. These events were a wake-up call that tensions existed regarding immigrants, rapid population growth, inequality, and alienation. Those tensions have led to the growth of sometimes violent right-wing movements in many countries. So moving toward sustainability requires dealing with fundamental social, political, and economic issues, not just adoption of environmental policies.

One of the mantras I repeat to undergraduate classes is that "sustainability is not simple." Sustainability planning does not mean doing just enough to brag about, or considering a limited set of environmental issues in one place. Rather, it requires deeper re-examination of all facets of "development" using different cognitive lenses than previously.

Three paradigmatic lenses are particularly important. First, "sustainability" requires a proactive, resultsoriented focus. To take the most obvious example, we have no choice but to reduce greenhouse gas emissions to virtually nothing within a generation or two if we want to have a livable planet. That will require radical changes in economies, societies, and lifestyles. Other needs are nearly as dramatic. In a world filled with weapons including nuclear and biological agents, we must commit ourselves to reduce violence. In a world in which growing inequities, conflict, and economic despair produce potentially dangerous social upheaval, we must address social injustices. With such sustainability threats, Charles Lindblom's "muddling through" philosophy of mid-twentieth century planning is no longer possible (Lindblom, 1959). Instead, new forms of advocacy planning seem needed within government, civil society, and academia. Planners and other professionals need to actively frame alternatives that will lead to greater long-term social and ecological well-being, and to work with all possible constituencies in order to move in those directions.
A second cognitive shift behind "sustainability" involves adopting a more long-term perspective. As has been pointed out by many, including the Brundtland Commission, author of the most widely used if imperfect definition of sustainable development, ${ }^{1}$ sustainability connotes a long-term approach to problem-solving. That's radical in modern societies that are heavily oriented towards the short term. It means, among other things, that we have to be more strategic in establishing institutions, social movements, inspirational examples, and collective understandings that will support longterm change. We also need to figure out ways to work around existing incentives for short-term thinking, many of them produced by economics, capitalism, and current forms of political economy. Many of our analytic tools must also be changed. Due to the existence of discount rates, for example, economic cost-benefit analysis has little ability to consider project costs and benefits more than 20 or 30 years into the future. Yet much longer-term analysis is important for sustainability planning. Also, within individual building projects the habit of separating construction costs from operating costs makes it difficult to incorporate long-term savings from resource efficiency up-front. Such structural impediments need to be changed.

Perhaps the most challenging cognitive shift is toward what might be called holistic or ecological thought-the ability to understand the dynamic, evolving, radically contingent, and interdependent nature of human and natural systems. This worldview is very different than that promoted by twentieth-century modernity, which embraced a more atomistic, mechanistic view of reality often labeled as "Cartesian" thought (Capra, 1996). Postmodernism began to deconstruct the misplaced modernist faith in scientific objectivity, pointing out the cultural relativism of many beliefs, but failed to propose anything else in its place (Norgaard, 1994). But an ecological worldview can supply both a sophisticated cognitive outlook, emphasizing the dynamic coevolution of systems, and a moral framework, based on those values necessary for all species to thrive on a small planet (see Table 1 and Figure 1).

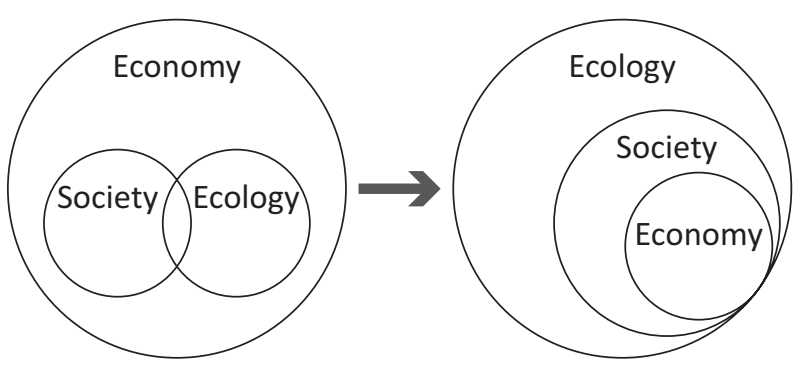

Figure 1. Sustainabilty as a transition from the modernist paradigm grounded in economics towards ecological thought.

\footnotetext{
${ }^{1}$ Development that "meets the needs of the present without jeopardizing the ability of future generations to meet their own needs" (World Commission on Environment and Development, 1987).
} 
Table 1. Modernist, postmodernist, and ecological worldviews.

\begin{tabular}{|c|c|c|c|}
\hline & Modernist Worldview & Postmodernist Worldview & Ecological Worldview \\
\hline Values & $\begin{array}{l}\text { Universal values based on } \\
\text { modern science }\end{array}$ & $\begin{array}{l}\text { Pluralistic values based on } \\
\text { cultural and cognitive } \\
\text { traditions }\end{array}$ & $\begin{array}{l}\text { Acknowledges pluralism but } \\
\text { also a shared core value set } \\
\text { based on common problems }\end{array}$ \\
\hline $\begin{array}{l}\text { Cognitive } \\
\text { Approach }\end{array}$ & $\begin{array}{l}\text { Atomistic (break problems } \\
\text { down into constituent parts; } \\
\text { view world as collection of } \\
\text { individual elements) }\end{array}$ & $\begin{array}{l}\text { Acknowledges multiple ways } \\
\text { of viewing the world }\end{array}$ & $\begin{array}{l}\text { Focuses on interrelationships } \\
\text { and dynamic, evolving } \\
\text { systems }\end{array}$ \\
\hline Core Influences & $\begin{array}{l}\text { Newtonian physics; } \\
\text { neoclassical economics }\end{array}$ & $\begin{array}{l}\text { Twentieth century physics } \\
\text { (relativity, uncertainty } \\
\text { principle) }\end{array}$ & $\begin{array}{l}\text { Ecological science; chaos } \\
\text { theory; systems theory; many } \\
\text { social theories }\end{array}$ \\
\hline $\begin{array}{l}\text { Political } \\
\text { Implications }\end{array}$ & $\begin{array}{l}\text { Reinforces centralized } \\
\text { authority }\end{array}$ & $\begin{array}{l}\text { Undermines centralized } \\
\text { authority }\end{array}$ & $\begin{array}{l}\text { Emphasizes flexible and } \\
\text { evolving relationships } \\
\text { between many different } \\
\text { institutions }\end{array}$ \\
\hline $\begin{array}{l}\text { Preferred } \\
\text { Planning Modes }\end{array}$ & $\begin{array}{l}\text { Rational, comprehensive } \\
\text { planning }\end{array}$ & $\begin{array}{l}\text { Decentralized local planning } \\
\text { to meet pluralistic community } \\
\text { needs; communication to gain } \\
\text { consensus on directions }\end{array}$ & $\begin{array}{l}\text { Emphasizes communication } \\
\text { and education to help evolve } \\
\text { understanding; advocacy } \\
\text { planning to achieve shared } \\
\text { goals; evolving incentives and } \\
\text { mandates between different } \\
\text { levels of government }\end{array}$ \\
\hline
\end{tabular}

Such an integrating, ecological mindset can be seen at work within the somewhat simplistic trope of the "Three E's" - environment, economy, and social equitywhich has been a mainstay of the sustainability discourse since Donella Meadows and others first surfaced the term in 1972 (Goldsmith, Allen, Allaby, Davoll, \& Lawrence, 1972; Meadows, Meadows, Randers, \& Behrens III, 1972). It can also be seen within recurrent attempts to link different scales of professional action (the building, site, neighborhood, district, city, region, state, nation, and world) within recent movements like the New Urbanism. Academic efforts to promote interdisciplinary or transdisciplinary sustainability-related courses likewise rest on this foundation of ecological thought, though such initiatives often founder within the silobased environment of academia. The ecological perspective is still in its infancy. Twentieth century modernity was heavily about specialization of disciplines, compartmentalization of knowledge, and the rise of supposedly objective experts, and it will take a long while to overcome these unfortunate norms. But this outlook is gaining ground and can be practiced by students and professionals alike.

Many smaller paradigm shifts may follow from these three fundamentals of the sustainability perspective. Developing "biophilic cities," which Timothy Beatley has proposed, means learning to see cities as a dynamic balance of green and gray landscapes and figuring out creative ways to improve this balance (Beatley, 2011). "Guerilla urbanism" or "tactical urbanism," championed by a number of community activists worldwide, means seeing urban contexts such as streets as an opportunity for short-term, grass-roots interventions that can challenge a stuck and dysfunctional business-as-usual (e.g. The Street Plans Collaborative, 2012). Seeing cities as places that are friendly for women, children, the elderly, people of color, LGBT communities, and the differently abled all require their own broadening of perspectives as well.

To sum up, sustainability planning requires three fundamental paradigm shifts: results-oriented problemsolving, a long-term perspective, and holistic or ecological thought. These new cognitive lenses may sound simple, but are highly challenging to bring about in practice. They themselves require a supportive framework of institutions, incentives, peer networks, and education. They require professionals to work collaboratively and openly with communities of all sorts in pursuit of collective learning and communication. They require resisting the siren lure of many incentives of modernity: academics avoiding the seduction of overly rarified theory and impenetrable language that will make their work irrelevant to practice; engineers moving away from the safety of outdated rulebooks and instead changing them; developers resisting financiers' desires to see them build what has been built before; and public officials developing a creative culture of governance rather than adhering to rigid bureaucratic rules. Moving towards sustainability will place new cognitive demands on professionals of all types. But it also offers new potential rewards, not least of which is the excitement that comes from creating a global community of social change agents actively responding to the challenges of the time. 


\section{Conflict of Interests}

The author declares no conflict of interests.

\section{References}

Beatley, T. (2011). Biophilic cities: Integrating Nature into urban design and planning. Washington, DC: Island Press.

Capra, F. (1996). The web of life: A new scientific understanding of living systems. New York: Anchor Books.

Goldsmith, E., Allen, R., Allaby, M., Davoll, J., \& Lawrence, S. (1972) Blueprint for survival. Boston: Houghton Mifflin.

Lindblom, C. E. (1959). The science of 'muddling through'. Public Administration Review, 19(2), 79-88.
Meadows, D., Meadows, D. L., Randers, J., \& Behrens III, W. W. (1972). The limits to growth. New York: Universe Books.

Norgaard, R. (1994). Development betrayed: The end of progress and a coevolutionary revisioning of the future. New York: Routledge.

Sustainable Oslo. (2016). Oslo, Norway-A sustainable Oslo. Retrieved from: http://oslonorwayasustainable oslo.weebly.com/oslo-overview.html

The Street Plans Collaborative. (2012). Tactical urbanism: Short-term action, long-term change. Retrieved from: https://issuu.com/streetplanscollaborative/docs/tac tical_urbanism_vol.1

World Commission on Environment and Development. (1987). Our common future. New York: Oxford University Press.

\section{About the Author}

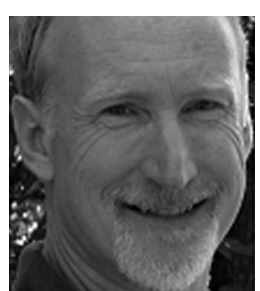

Stephen M. Wheeler is a Professor in the Department of Human Ecology at the University of California at Davis. His doctorate in city and regional planning is from U.C. Berkeley. Wheeler has written widely on urban sustainability topics and is the author of Planning for Sustainability: Creating Livable, Equitable, and Ecological Communities and Climate Change and Social Ecology. He is also lead editor of The Sustainable Urban Development Reader (with Timothy Beatley). Other academic interests include climate change planning, regional planning, and urban morphology. 